\title{
Atrial fibrillation after lung surgery: incidence, underlying factors, and predictors
}

\author{
Reza Bagheri ${ }^{1}$, Yousef Yousefi $^{1}$, Reza Rezai ${ }^{1}$, Vahab Azemonfar ${ }^{2}$, Farideh Golhasani Keshtan ${ }^{3}$ \\ ${ }^{1}$ Lung Diseases Research Center, Mashhad University of Medical Sciences, Mashhad, Iran \\ ${ }^{2}$ Student Research Committee, Faculty of Medicine, Mashhad University of Medical Science, Mashhad, Iran \\ ${ }^{3}$ Department of Physiology, Mashhad University of Medical Sciences, Mashhad, Iran
}

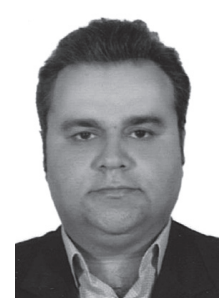

Kardiochirurgia i Torakochirurgia Polska 2019; 16 (2): 53-56

\begin{abstract}
Introduction: Cardiac complications are the second most common cause of morbidity and mortality in patients subjected to thoracic surgery after respiratory complications. Postoperative arrhythmia is one of the most common cardiac complications in these patients. It leads to morbidity, increased hospitalization, and high costs for patients.

Aim: To determine the incidence of atrial fibrillation after lung resection and determine the underlying factors and predictors of this problem.

Material and methods: The participants in this study were composed of all patients who were subjected to lung resection surgery in the past 4 years. The demographic data of the patients and possible postoperative complications, including the incidence of atrial fibrillation, were extracted from patient records. The statistical analysis of data was performed after data collection.

Results: The incidence of postoperative atrial fibrillation (POAF) in the present study was $7.6 \%(n=20)$, mostly in patients who had a lung parenchyma resection. It occurred due to malignancy ( $n=16)$, squamous cell carcinoma $(n=9)$, adenoid cystic carcinoma $(n=5)$, and metastasis $(n=2)$. The POAF occurred in $34.2 \%$ of pneumonectomy cases and $4.5 \%$ of lobectomy cases, out of whom $60 \%$ were male. There was a significant difference between the two groups of arrhythmia and non-arrhythmia groups regarding the age range. The mean ages of patients with and without arrhythmias were $56.45 \pm 18.2$ and $44.76 \pm 17.2$, respectively.

Conclusions: Pulmonary malignant pathologies are more likely to develop POAF due to the need for lung resection and possibly mediastinal lymphadenectomy that stimulates the heart and pericardium and the vagus nerve.
\end{abstract}

Key words: atrial fibrillation, complication, lung resection surgery.

\section{Streszczenie}

Wprowadzenie: Powikłania sercowe to druga najczęstsza przyczyna zachorowalności i śmiertelności u pacjentów poddawanych operacjom klatki piersiowej - po powikłaniach oddechowych. Arytmia pooperacyjna jest u tych osób jednym z najczęstszych powikłań sercowych. Stanowi ona przyczynę zachorowalności, wydłużenia hospitalizacji i wysokich kosztów dla pacjentów.

Cel: Zbadanie częstości występowania migotania przedsionków po resekcji płuc oraz określenie czynników leżących u podstaw tego problemu i czynników predykcyjnych.

Materiat i metody: W badaniu wzięli udział wszyscy pacjenci, którzy zostali poddani resekcji płuc w ciągu ostatnich 4 lat. Dane demograficzne pacjentów i informacje na temat możliwych powikłań pooperacyjnych, w tym częstości występowania migotania przedsionków, uzyskano z dokumentacji pacjentów. Analizę statystyczną przeprowadzono po zebraniu danych.

Wyniki: Częstość występowania pooperacyjnego migotania przedsionków (POAF) w badaniu wynosiła 7,6\% $(n=20)$, głównie u pacjentów po resekcji miąższu płuca. Migotanie przedsionków występowało u chorych operowanych z powodu nowotworu $(n=16)$, raka płaskonabłonkowego $(n=9)$, raka gruczołowo-torbielowatego $(n=5)$ i przerzutów $(n=2)$. Pooperacyjne migotanie przedsionków stwierdzono w 34,2\% przypadków pneumonektomii i w 4,5\% przypadków lobektomii, z których $60 \%$ stanowili mężczyźni. Wykazano istotną różnicę między grupami z arytmią i bez arytmii pod względem przedziału wiekowego. Średni wiek pacjentów z arytmią i bez arytmii wynosił odpowiednio $56,45 \pm 18,2$ i 44,76 $\pm 17,2$ roku.

Wnioski: U pacjentów z nowotworami złośliwymi płuc częściej dochodzi do POAF ze względu na konieczność resekcji płuc i ewentualnie limfadenektomii śródpiersia, co stymuluje serce i osierdzie oraz nerw błędny.

Słowa kluczowe: migotanie przedsionków, powikłanie, resekcja płuc.

Address for correspondence: Yousef Yousefi, Lung Diseases Research Center, Mashhad University of Medical Sciences, 9137913316 Mashhad, Iran, e-mail: Itrc@mums.ac.ir

Received: 11.03.2019, accepted: 23.05.2019. 


\section{Introduction}

Postoperative atrial fibrillation (POAF) is a common complication following cardiac and non-cardiac surgery [1]. The incidence of POAF depends on the type of surgery. To clarify, the incidence rate of POAF was highest after coronary artery procedures (up to 55\%) or isolated coronary bypass surgery (20-40\%), followed by non-cardiac surgery of the chest (10-20\%), and general non-cardiac non-thoracic surgery $(0.37-1 \%)[2,3]$.

Although POAF is often known as a temporary benign operation-related problem, it increase the risk of adverse events, including transient or permanent stroke, acute myocardial infarction, and mortality. The POAF mostly occurs on the second or third day after the surgery, which can lead to an increased rate of hypotension, heart failure (HF), and embolism $[4,5]$.

The predisposing factors for the occurrence of POAF include 50 years of age or more, male gender, history of congestive heart failure, arrhythmias, peripheral vascular disease, and extensive pulmonary resection and transfusion during surgery. Postoperative atrial tachyarrhythmias prolong the duration of hospitalization and increase the costs of treatment [6-10], emphasizing the need for prevention and treatment.

Table I. Demographic information of the participants

\begin{tabular}{|c|c|c|c|}
\hline \multicolumn{2}{|l|}{ Parameter } & Arrhythmia & Non-arrhythmia \\
\hline \multicolumn{2}{|c|}{ Age, mean \pm SD } & $56.45 \pm 18.2$ & $44.76 \pm 17.2$ \\
\hline \multirow{2}{*}{$\begin{array}{l}\text { Sex, } \\
n(\%)\end{array}$} & Male & $12(60)$ & $160(65)$ \\
\hline & Female & $8(40)$ & $83(35)$ \\
\hline \multirow{2}{*}{$\begin{array}{l}\text { Location, } \\
n(\%)\end{array}$} & Left & $11(8)$ & $126(92)$ \\
\hline & Right & $9(7.3)$ & $115(92.7)$ \\
\hline \multirow{4}{*}{$\begin{array}{l}\text { Type } \\
\text { of resection, } \\
n(\%)\end{array}$} & Lobectomy & $7(4.5)$ & $148(95.5)$ \\
\hline & Pneumonectomy & $13(34.2)$ & $25(65.8)$ \\
\hline & Segmentectomy & $0(0)$ & $66(100)$ \\
\hline & Bilobectomy & $0(0)$ & $4(100)$ \\
\hline
\end{tabular}

Table II. Evaluation of some variables regarding postoperative atrial fibrillation

\begin{tabular}{|c|c|c|c|c|}
\hline \multicolumn{3}{|l|}{ Parameter } & \multirow{2}{*}{\multicolumn{2}{|c|}{$\begin{array}{c}N(\%) \\
12(60)\end{array}$}} \\
\hline \multirow{2}{*}{\multicolumn{2}{|c|}{ Sex }} & Male & & \\
\hline & & Female & & $8(40)$ \\
\hline \multirow{4}{*}{\multicolumn{2}{|c|}{$\begin{array}{l}\text { Type } \\
\text { of resection }\end{array}$}} & Lobectomy & & $7(4.5)$ \\
\hline & & Pneumonectomy & & $13(34.2)$ \\
\hline & & Segmentectomy & & $0(0)$ \\
\hline & & Bilobectomy & & $0(0)$ \\
\hline \multirow[t]{6}{*}{ Pathology } & \multirow[t]{3}{*}{ Malignant } & \multirow[t]{2}{*}{ Primary lung cancer } & SCC & $9(45)$ \\
\hline & & & $\mathrm{ACC}$ & $5(25)$ \\
\hline & & Metastasis & & $2(10)$ \\
\hline & \multirow[t]{3}{*}{ Benign } & Bronchiectasis & & $1(5)$ \\
\hline & & Tuberculosis & & $2(10)$ \\
\hline & & Hydatid cyst & & $1(5)$ \\
\hline
\end{tabular}

There are two approaches to the treatment of POAF, namely heart rate control and rhythm control. On the basis of the literature, the heart rate control strategy is more effective than the rhythm control strategy for the treatment of POAF [11]. As a result, various prophylactic and therapeutic drug guidelines, such as digoxin, amiodarone, diltiazem, and $\beta$-blockers, have been used to solve this problem [12]. However, there is no specific guideline for the prevention and treatment of POAF since there have been controversies over the obtained results of the existing studies.

\section{Aim}

The aim of the current study was to determine the incidence of POAF in patients with thoracic surgery. Moreover, this study further investigated the potential causes and risk factors of POAF among these patients, as well as the duration of hospitalization and therapeutic procedures.

\section{Material and methods}

This retrospective study was conducted on 263 patients undergoing lung resection surgery. Patients in this study were subjected to anatomical or non-anatomical resection of the lungs for various causes, including lung cancer and lung metastases, or benign pathologies (e.g., bronchiectasis and lung hydatid cyst). Data collection was accomplished through recording the demographic information of patients (i.e., age and gender), causes of pulmonary resection, primary diagnosis of the disease, postoperative complications (e.g., pulmonary disease), cardiac complications (e.g., atrial fibrillation), comorbidity, and mortality rate.

\section{Statistical analysis}

Statistical analysis was performed to identify the important risk factors for postoperative arrhythmias. The variables, including age, gender, type of pathology, type of lung resection, and the relationship between postoperative arrhythmias, were analyzed in this study.

\section{Results}

This retrospective study involved the analysis of 263 patients who were subjected to lung resection at Ghaem and Imam Reza Hospital between January 2013 and March 2017. The demographic characteristics of the patients are presented in Table I. The incision in all patients was standard posterolateral thoracotomy. There was a significant difference between the patients in the arrhythmia and non-arrhythmia group regarding the age. The mean ages of patients with and without arrhythmias were $56.45 \pm 18.2$ and $44.76 \pm 17.2$, respectively. Considering gender distribution, 172 (65.3\%) patients were male. The surgical procedures performed on the patients were lobectomy (58.9\%), pneumonectomy (14.4\%), segmentectomy (25.9\%), and bilobectomy (1.5\%). Tables II tabulates the outcomes of the POAF for the investigated subjects.

As can be seen, POAF occurred in 20 (7.6\%) patients, out of whom 12 (60\%) were male. Most of the POAF cases 
(16 out of 20) were patients with malignant pathologies. The POAF was observed in 13 (34.2\%) and 7 (4.5\%) patients who were subjected to pneumonectomy and lobectomy, respectively. However, in patients with segmentectomy and lobectomy, there were no arrhythmias. In 11 (8\%) cases, POAF occurred on the left side, meaning that the incidence rate of POAF in those was higher than on the right side, 9 (7.3\%). The morbidity rates were $7.6 \%, 2.6 \%, 2.6 \%$, and $1.1 \%$, in cases with arrhythmia, pneumonia, surgical site infection, and stump fistula, respectively. As can be seen in Table I, the main causes of mortality were myocardial infarction, pulmonary emboli, and congestive heart failure in 5 (1.9\%), 3 (1.14\%), and 20 (7.6\%) cases. With regard to the type of resection and pathology, it can be observed that the incidence rate of POAF was higher among men than women; the type of resection with the highest incidence is pneumonectomy. The incidence of malignant pathology is higher than that of benign pathology in POAF (Table II).

\section{Discussion}

The POAF affects more than one million Americans annually. It can increase risk factors of early postoperative stroke [13]. The POAF is common perioperative arrhythmia; however, it has not been deeply investigated. The reported incidence rates of POAF varied widely from $4 \%$ to $60 \%$ since the published studies have included different patient populations in terms of the surgery types and patient characteristics [14].

The POAF is an independent predictor of numerous adverse outcomes, including an increased risk of stroke, reoperation for bleeding, infection, renal or respiratory failure, cardiac arrest, cerebral complications, need for permanent pacemaker placement, and all-cause 30-day and 6-month mortality [15]. Prophylaxis with amiodarone, beta-blockers, or statins reduces postoperative atrial fibrillation after non-cardiac surgery, and there is a tendency toward the administration of calcium channel blockers. On the other hand, digoxin may be associated with an increased risk of postoperative atrial fibrillation [16].

In the current study, 20 of 263 patients undergoing lung resection surgery had POAF. The incidence in lung resections was high, including 13 cases of pneumonectomy, 4 cases of lobectomy due to malignancy, and 4 cases due to benign pathologies. The reason for this is probably due to more cardiopulmonary manipulation and mediastinal lymphadenectomy in pulmonary malignant pathologies that stimulate the heart and pericardium.

In a study conducted by Takuya on 607 patients, it was concluded that the incidence of POAF was higher in lobectomy than segmentectomy regarding lung cancer in stage IA [10]. In most studies, aging was mentioned as a significant predictor of POAF occurrence $[6,9,17,18]$. In the current study, there was a significant difference between the patients with arrhythmia and non-arrhythmia groups in terms of age. The mean ages in patients with and without arrhythmias were 56.45 (18.2\%) and 44.76 (17.2\%), respectively.
Male gender has been mentioned in numerous studies as a predictor of POAF [7, 9]. In a study performed by Ngu et al. [8], it was concluded that gender did not affect the occurrence of POAF ( $p=0.27)$. Therefore, they concluded that gender was an ineffective factor in postoperative atrial fibrillation after cardiac surgery [8]. However, POAF prevalence was higher in men in the present study. The mean duration of hospitalization for patients with POAF was longer in most studies than in patients without arrhythmias [17]. In the current study patients with postoperative atrial fibrillation required longer hospitalization. The amount of lung tissue resection was considered in some studies as a predictive factor for the occurrence of $\operatorname{POAF}[7,9,10]$. In the present study, there was a higher incidence of POAF in patients with pneumonectomy and lobectomy. The incidence of POAF was lower in patients with benign illness because the procedure removed less lung tissue.

The presence of comorbidities in patients could increase the incidence of POAF. In a study performed by Darvis, the history of atrial fibrillation and the use of antiarrhythmic drugs were mentioned as the most important predictors of postoperative atrial fibrillation [6]. In a study by Kavurmaci et al., the presence of COPD led to an increase in the incidence of POAF [17]. In a study by Garner, postoperative infection was one of the most important factors in the occurrence of POAF. However, the obtained results of the current study did not yield any support for the association of comorbidity and POAF among patients. Patients with a history of arrhythmias and thyroid disorders were excluded from the present study. Although there has been no consensus on the suitable treatment for POAF [2], in metaanalysis studies and systematic reviews, amiodarone and magnesium sulfate were introduced as effective and safe drugs [12]. In an ideal situation, a possible multifaceted approach to face some challenge might include better baseline risk scoring to predict POAF, intraoperative measures to control the known predisposing factors in the high POAF scores, and more effective early and midterm anticoagulation management for patients with POAF. Such an approach should possibly include the administration of direct factor $\mathrm{Xa}$ inhibitors to the patient suffering from POAF as part of a dedicated trial $[18,19]$.

\section{Conclusions}

The POAF is one of the most common cardiac complications following thoracic surgery and pulmonary resection, which can lead to an increase in morbidity, hospitalization, and treatment costs. In the current study, most POAF cases occurred in patients with extensive lung resections, often due to malignant pathologies. Moreover, POAF occurred in $34.2 \%$ of pneumonectomy cases and $4.5 \%$ of lobectomy cases. Pulmonary malignant pathology is associated with an increased risk for POAF due to cardiopulmonary manipulation and possibly mediastinal lymphadenectomy, which stimulates the pericardium and the vagus nerve. 


\section{Disclosure}

The authors report no conflict of interest.

\section{References}

1. Hogue CW, Hyder ML. Atrial fibrillation after cardiac operation: risks, mechanisms, and treatment. Ann Thorac Surg 2000; 69: 300-306.

2. Passman RS, Gingold DS, Amar D, Lloyd-Jones D, Bennett CL, Zhang H, Rusch VW. Prediction rule for atrial fibrillation after major noncardiac thoracic surgery. Ann Thorac Surg 2005; 79: 1698-1703.

3. Hassanzadeh Delui M, Kamandi M, Feiz Disfani H, Dezyani J, Keyvani V. Investigating the effect of inflammation on atrial fibrillation occurrence by measuring highly sensitive C-reactive protein (hs-CRP). J Cardiothorac Med 2014; 2: 167-171.

4. Riber LP, Christensen TD, Jensen HK, Hoejsgaard A, Pilegaard HK. Amiodarone significantly decreases atrial fibrillation in patients undergoing surgery for lung cancer. Ann Thorac Surg 2012; 94: 339-346.

5. Moeinipour A, Hoseinikhah H, Morovatdar N, Ghorbanzadeh A, Akbari M, Mirshahpanah M, Moeinipour A. Outcomes of on-pump coronary artery bypass grafting in patients with metabolic syndrome in Mashhad, Iran. J Cardiothorac Med 2017; 5: 187-191.

6. Hollings DD, Higgins RS, Faber LP, Warren WH, Liptay MJ, Basu S, Kim AW. Age is a strong risk factor for atrial fibrillation after pulmonary lobectomy. Am J Surg 2010; 199: 558-561.

7. Iwata T, Nagato K, Nakajima T, Suzuki H, Yoshida S, Yoshino I. Risk factors predictive of atrial fibrillation after lung cancer surgery. Surg Today 2016; 46: 877-886.

8. Ngu J, Tran D, Rubens F. Effect of sex on incidence of post-operative atrial fibrillation in cardiac surgery patients. Can J Cardiol 2018; 34: e5.

9. Onaitis M, D'amico T, Zhao Y, O'brien S, Harpole D. Risk factors for atrial fibrillation after lung cancer surgery: analysis of the Society of Thoracic
Surgeons general thoracic surgery database. Ann Thorac Surg 2010; 90: 368-374.

10. Ueda T, Suzuki K, Matsunaga T, Takamochi K, Oh S. Postoperative atrial fibrillation is less frequent in pulmonary segmentectomy compared with lobectomy. Gen Thorac Cardiovasc Surg 2018; 66: 95-100.

11. Carlsson J, Miketic S, Windeler J, Cuneo A, Haun S, Micus S, Walter S, Tebbe U; STAF Investigators. Randomized trial of rate-control versus rhythm-control in persistent atrial fibrillation: the Strategies of Treatment of Atrial Fibrillation (STAF) study. J Am Coll Cardiol 2003; 41: 1690-1696.

12. Riber LP, Larsen TB, Christensen TD. Postoperative atrial fibrillation prophylaxis after lung surgery: systematic review and meta-analysis. Ann Thorac Surg 2014; 98: 1989-1997.

13. Amar D. Perioperative atrial tachyarrhythmias. Anesthesiology 2002; 97 : 1618-1623.

14. Danelich IM, Lose JM, Wright SS, Asirvatham SJ, Ballinger BA, Larson DW, Lovely JK. Practical management of postoperative atrial fibrillation after noncardiac surgery. J Am Coll Surg 2014; 219: 831-841.

15. Yadava M, Hughey AB, Crawford TC. Postoperative atrial fibrillation: incidence, mechanisms, and clinical correlates. Heart Fail Clin 2016; 12: 299308.

16. Oesterle A, Weber B, Tung R, Choudhry NK, Singh JP, Upadhyay GA. Preventing postoperative atrial fibrillation after noncardiac surgery: a metaanalysis. Am J Med 2018; 131: 795-804.

17. Kavurmaci O, Akcam TI, Ergonul AG, Turhan K, Cakan A, Cagirici U. Is the risk of postoperative atrial fibrillation predictable in patients undergoing surgery due to primary lung cancer? Heart Lung Circ 2018; 27: 835-841.

18. Muranishi Y, Sonobe M, Menju T, Aoyama A, Chen-Yoshikawa TF, Sato T, Date $\mathrm{H}$. Atrial fibrillation after lung cancer surgery: incidence, severity, and risk factors. Surg Today 2017; 47: 252-258.

19. Bruno VD, Ascione R. Postoperative atrial fibrillation: still in search of truth or a neglected complication? J Thorac Cardiovasc Surg 2018; 155: 236-237. 